Received $\quad 16.01 .2018$ Reviewed $\quad 03.04 .2018$ Accepted 16.04.2018

A - study design

B - data collection

C - statistical analysis

D - data interpretation

$\mathbf{E}$ - manuscript preparation

F - literature search

\section{Analysis of effective factors on agricultural water management in Iran}

Yaser FEIZABADI ${ }^{\text {ABCDEF } \bowtie}$, Effat Masomi GORJI ${ }^{\text {BEF }}$

Islamic Azad University, Qaemshahr Branch, Department of Agricultural Economics, Mazandaran Province, 4761633916 Qaemshahr, Iran; e-mail: yaser.feizabadi@qaemiau.ac.ir, efat.masomi67@gmail.com

For citation: Feizabadi Y., Gorji E.M. 2018. Analysis of effective factors on agricultural water management in Iran. Journal of Water and Land Development. No. 38 p. 35-41. DOI: 10.2478/jwld-2018-0040.

\begin{abstract}
The aim of this study was to analyse the factors affecting agricultural water management in Iran based on irrigation experts' point of view using factor analysis approach. The results indicated that conservation of modern irrigation equipment, promoting farmers' knowledge, creating a watercourse (surface water collection), imposing a ban on digging new wells and educating the effectiveness of pressurized irrigation system were all known as the most important factors affecting agricultural water management. Moreover, factor analysis results showed that five factors influencing agricultural water management (institutional and legislative, educational and promotional, economic, technical and farming system) explained $64.29 \%$ of the total variance. At the end, some policy suggestions were provided in order to improve agricultural water management in Iran.
\end{abstract}

Key words: agriculture, factor analysis, Iran, water management

\section{INTRODUCTION}

Drought crisis has raised concerns about climate change in near future in Iran. As predicted by experts, water shortage will be experienced on a global scale in the coming decades so that the necessity and the absence of this vital material will be more obvious and more attention will be given to improvement of water use efficiency. The reason for this is that water is one of the fundamental resources used in producing goods and providing services. Agricultural sector is the biggest water consumer in Iran so that $93 \%$ of the whole water resources has been allocated to this sector [YOUSEFI et al. 2017]. As shown by the report made by the Soil and Water Management Research Institute in Iran, about $67 \%$ of water is consumed in the agricultural sector in developing countries while this rate is about $90 \%$ in Iran [MOHAMMADI et al. 2009]. This is also the case about Iran because this country is a developing country located in the arid and semi-arid part of the world where water scarcity is one of the main issues [HoSSEINZAD et al. 2014]. Wa- ter consumption in Iran is 96 billion $\mathrm{m}^{3}$ per year. This consumption rate in comparison with 120 billion $\mathrm{m}^{3}$ of renewable water in the country shows that at least $80 \%$ of the water resources is used up annually. However, according to the international standards, we have the right to use only 40 to $50 \%$ of the fresh water that can be extracted in our country [SHOA et al. 2015]. Unfortunately, in some areas of the country, $140 \%$ of the renewable water is consumed, which is one of the major problems in water management in Iran. In Iran, the agricultural sector is the main consumer of water, consuming over $90 \%$ of the country's water [BAGHERI et al. 2014]. This sector has a constructive and valuable role in the national economy of Iran so that $20 \%$ of GDP, $14 \%$ of employment and $80 \%$ of the food production in the country belong to this sector [DABIRI et al. 2013].

Considering the fact that water scarcity is felt the most in the agricultural sector, it is inevitable to use the water resources in this sector efficiently or to manage the water as properly as possible. Water is a vital resource for farmers and it is very important to 
ensure access to water in order to reduce the risk faced by farmers. The fulfilment of this important issue will provide food security. Agricultural water management is a systemic approach toward on-farm water control so that it leads to proper management of water on farms. It also leads to proper management of water in order to supply the irrigation and drainage needs in conditions where there are physical, social, and governmental problems in the production systems [FORREST 2002]. The purpose of effective management of agricultural water is to increase economic performance and to reduce water or energy consumption [PANDA et al. 2004; PANDY et al. 2000]. Therefore, agricultural water management seems necessary especially in areas that are facing water shortages so that we can attain the most efficiency of water resources. In arid countries, maintaining the sustainability of water systems requires the use of more systematic principles and plans. Iran is one of these countries the agricultural lands of which are faced with water restrictions as this country is located at the belt of semi-arid and arid areas. The agricultural sector has encountered serious challenges especially after the frequent droughts in recent years and uncontrolled exploitation of water resources. The average annual precipitation in Iran is about $250 \mathrm{~mm}$, which is about one-third of the world's average rainfall. In addition, the climatic conditions in Iran are such that the water evaporating in this country is three times as much as the average evaporation in the world [SHAHRESTANI 2014]. The figures announced by Iranian Ministry of Agriculture show that $700 \mathrm{~g}$ of crops is produced per cubic meter of water consumed in the agricultural sector, while the global standard for this amount of water is $2 \mathrm{~kg}$ of crop. Thus, improving water efficiency in agricultural sector is necessary, due to the limitations of water resources and the growing population of the country [PANAHI et al. 2009]. Monitoring and evaluation of drought would allow for undertaking activities in agricultural production, water management in rural areas, irrigation and protection of natural resources in agriculture [KASPERSKA-WOŁOWICZ, ŁABĘDZKI 2006]. Due to inappropriate and excessive exploitation of water resources, unfortunately Iran is facing serious limitations in supplying the water needed in the agricultural sector, which has created various challenges for achievement of the objectives of agricultural water management. Lack of technical knowledge, attitude and skills of farmers and in general farmers' lack of training regarding the use of correct methods of agricultural water management are among the most important reasons for low productivity and irrigation efficiency in Iran. Several studies have been conducted inside and outside the country regarding agricultural water management and analysis of its underlying factors.

HOSSEINZAD et al. [2014] investigated the basis and mechanisms of agricultural water management in Tabriz plain. They first classified the problems and factors affecting water resources management and then identified the indicators of agricultural water management by factor analysis. Imbalance between the operating wells and the area of the fields under cultivation, salinity of the groundwater due to irregular usage of this resource and drawdown of groundwater were known as the first three prior problems of agricultural water management of the region. The results indicated that $61 \%$ of the variance of the total water management indices has been defined by factors of surface and ground water. Therefore, reducing water extracted from the wells and optimum use of surface water for extending irrigated farms will be effective in water resources management of the region.

GHANIAN et al. [2013] studied the attitudes of farmers toward participatory management of water resources, and the factors affecting it in Khuzestan province of Iran. They showed that the factors affecting irrigation management can be categorized into three groups: technical, management, and regulation factors.

GHOLAMI et al. [2016] showed that the SWAT model can be an effective and useful tool for the assessment and optimal management of water and soil resources in Iran.

$\mathrm{KOH}$ [2002] conducted a study entitled "Status of agricultural water in Korea: Water use and water quality", in which they showed that integration of the laws related to water use improvement is important in water management and found that consistent rules need to be developed and formulated in the field of water management.

SAMIAN et al. [2015] explored the factors affecting agricultural water management in Hamedan Province of Iran. The results of their research using factor analysis method showed that four factors including the legislative and institutional factor, technical and knowledge-related factor, economic factor and social factor affect the optimal management of agricultural water in Hamedan Province.

Sun et al. [2017] investigated and prioritized the effects of five indices including technology, engineering, management, environment and economy on agricultural water management in northern China using AHP approach. The results of their research indicated that management and engineering have the greatest impact on agricultural water management in the area under study. Their study provided a theoretical basis in improving the level of agricultural water management and water use efficiency in irrigation districts of northern China.

In line with previous studies, agricultural water management in Iran is to recognize its underlying factors so that it can have an optimal management for agricultural water consumption. Undoubtedly, awareness of the factors affecting agricultural water management can pave the way for optimal use of agricultural water resources in Iran. This study aims to explore and prioritize the factors affecting agricultural water management in Iran from the irrigation experts' point of view. 


\section{METHODS}

To reach the main goal of study, a questionnaire was distributed among 185 experts including faculty members of Irrigation Department at Islamic Azad University and also irrigation experts of Agricultural organization of Islamic republic of Iran. After asking 30 questions, 23 components affecting agricultural water management were finally extracted, and Cronbach's alpha coefficient was obtained $85 \%$, which indicates an acceptable level of reliability. These components were assessed using five-point Likert scale including five options: very low, low, medium, high and very high (numbers one, two, three, four, and five were given to these options respectively), and the experts were asked to score these components based on their degree of importance. They were then analyzed through inferential statistics (Student $t$-test and factor analysis) with the help of SPSS software Version 16. First, the importance degree of the components was identified using Student $t$-test. Obviously, the components that have a significant higher mean score will have more importance. Later, we used factor analysis to reduce the number of components in a few main ones as the factors underlying agricultural water management and to determine the factor loading of each component. Factor analysis is one of the multivariate methods in which there are no independent and dependent variables; rather all variables are interdependent. The fundamental issue in factor analysis is whether it is possible to convert a large number of main variables into a smaller set of variables with minimal information loss. Today, factor analysis is among the statistical analysis techniques used in a wide range of sciences including the humanities, agriculture and of course current research method.

\section{RESULTS AND DISCUSSION}

\section{PRIORITIZING THE FACTORS AFFECTING AGRICULTURAL WATER MANAGEMENT}

We raised 23 questions in order for the experts to express their views about the importance of components affecting agricultural water management by giving score one (very low) to five (very high) in Likert scale. Then we prioritized the components based on the mean obtained from the Student $t$-test.

Based on the research findings presented in Table 1, the importance of all components affecting water management from experts' point of view was assessed significantly high. Moreover, among the existing components, conservation of modern irrigation equipment, promotion of farmers' knowledge, creating watercourse (collecting the surface water), imposing a ban on digging new wells, and educating the effectiveness of pressurized irrigation system were prioritized as the first to fifth factors affecting agricultural water management from experts' point of view.

\section{FACTOR ANALYSIS OF THE FACTORS AFFECTING AGRICULTURAL WATER MANAGEMENT}

We have used factor analysis in this study to have a more precise and detailed analysis of the data and to

Table 1. Prioritization of the components affecting water management (Student $t$-test), number $=185$

\begin{tabular}{|c|c|c|c|}
\hline Component & Mean & $S D$ & $\begin{array}{c}\text { Percentage } \\
\text { of significance }\end{array}$ \\
\hline Conservation of modern irrigation equipment & 4.25 & 0.763 & 0.00 \\
\hline Promoting farmers' knowledge & 4.10 & 0.863 & 0.03 \\
\hline Creating watercourse (collecting the surface water) & 3.99 & 0.804 & 0.00 \\
\hline Imposing a ban on digging new wells & 3.99 & 0.835 & 0.00 \\
\hline Educating the effectiveness of pressurized irrigation system & 3.99 & 0.815 & 0.01 \\
\hline Educating the effectiveness of water transmission using pipes & 3.98 & 0.730 & 0.00 \\
\hline Educating the determination of appropriate seeding depth & 3.97 & 0.833 & 0.00 \\
\hline Whole role of education and promotion & 3.95 & 0.755 & 0.02 \\
\hline Impact of integration on water efficiency & 3.95 & 0.804 & 0.07 \\
\hline Impact of new irrigation methods on water efficiency & 3.95 & 0.835 & 0.00 \\
\hline Educating the impact of improper slope of channel & 3.94 & 0.746 & 0.00 \\
\hline Impact of farm management on water efficiency & 3.92 & 0.714 & 0.00 \\
\hline Impact of roughness of land on water efficiency & 3.92 & 0.819 & 0.00 \\
\hline Role of Agricultural Water Cooperation ${ }^{1)}$ & 3.91 & 0.833 & 0.03 \\
\hline Distance between water resource and farm & 3.89 & 0.678 & 0.00 \\
\hline Optimal determination of water rate & 3.89 & 0.855 & 0.02 \\
\hline Role of performance insurance & 3.87 & 0.800 & 0.00 \\
\hline Impact of land ownership on water consumption & 3.81 & 0.689 & 0.00 \\
\hline Role of government's supportive policies & 3.80 & 0.951 & 0.00 \\
\hline Educating the impact of growing season length (GSL) on water consumption & 3.78 & 0.910 & 0.00 \\
\hline Impact of cropping pattern on water consumption & 3.76 & 0.914 & 0.00 \\
\hline Impact of modern irrigation methods on reduction of costs & 3.73 & 0.520 & 0.01 \\
\hline Impact of modern irrigation methods on farmers' productivity & 3.41 & 0.668 & 0.00 \\
\hline
\end{tabular}

1) Agricultural Water Cooperation is a national association which aims agricultural water management and raising irrigation effectiveness. Source: own study. 
reduce the number of variables in a few main factors underlying agricultural water management. The results of this analysis are presented in the following tables and chart. At first, adequacy of sampling was assessed using the Kaiser-Meyer-Olkin (KMO) index and Bartlett's test, the results of which can be seen in Table 2. Since the KMO index is 0.883 (greater than $0.7)$, it can be argued that the data are suitable for factor analysis. In addition, the $p$-value of Bartlett's test is smaller than 0.05 , indicating appropriateness of factor analysis to identify the structure.

Table 2. Bartlett's test and KMO index

\begin{tabular}{|l|c|}
\hline \multicolumn{1}{|c|}{ Test } & Value \\
\hline Kaiser-Meyer-Olkin measure of sampling adequacy & 0.883 \\
\hline Bartlett's test of sphericity & \\
- approx. Chi-Square & $3.157 \mathrm{E} 3$ \\
- degree of freedom & 435 \\
- level of significance & 0.000 \\
\hline
\end{tabular}

Source: own study.

Table 3 summarizes the variables used in the factor analysis in five components. The first variable has the maximum eigenvalue, i.e. $4.13 \%$, accounting for the greatest amount of variance in the dependent variable, i.e. $24.29 \%$. In general, these five components account for $64.29 \%$ of the total variance.

Figure 1 shows the graphic representation of each one of the extracted factors. The eigenvalues for just first five factors are greater than one. That is why these five factors remain in the model, which are as follow: institutional and legislative, educational and promotional, economic, technical and farming system factors.
Table 3. Total variance distribution

\begin{tabular}{|c|c|c|c|}
\hline $\begin{array}{c}\text { Com- } \\
\text { ponent }\end{array}$ & $\begin{array}{c}\text { Eigen- } \\
\text { value }\end{array}$ & $\begin{array}{c}\text { Variance percentage } \\
\text { of eigenvalue }\end{array}$ & $\begin{array}{c}\text { Percentage of } \\
\text { cumulative variance }\end{array}$ \\
\hline 1 & 4.130 & 24.293 & 24.293 \\
\hline 2 & 1.788 & 14.461 & 38.753 \\
\hline 3 & 1.428 & 10.402 & 49.156 \\
\hline 4 & 1.212 & 9.132 & 58.288 \\
\hline 5 & 1.020 & 6.002 & 64.290 \\
\hline
\end{tabular}

Source: own study.

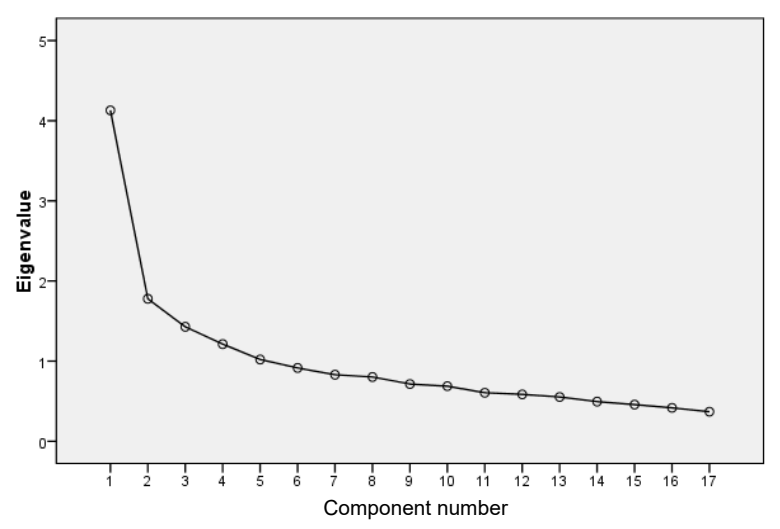

Fig. 1. Graphic representation of the extracted factors; source: own study

Table 4 shows five main factors affecting agricultural water management accompanied by their components and factor loadings.

It should be noted that the factors were named based on the components available in each factor, and attempts were made to create the greatest consistency between the name of the factors and the components

Table 4. Determining main factors affecting agricultural water management accompanied by their components and factor loadings

\begin{tabular}{|c|c|c|}
\hline Factor & Variable & Factor loading \\
\hline \multirow{5}{*}{$\begin{array}{l}\text { Institutional and legislative } \\
\text { factor }\end{array}$} & role of government's supportive policies & 0.655 \\
\hline & creating watercourse (collecting the surface water) & 0.559 \\
\hline & imposing a ban on digging new wells & 0.547 \\
\hline & optimal determination of water rate & 0.522 \\
\hline & role of performance insurance & 0.519 \\
\hline \multirow{7}{*}{$\begin{array}{l}\text { Educational and promotional } \\
\text { factor }\end{array}$} & promoting farmers' knowledge & 0.795 \\
\hline & educating the determination of appropriate seeding depth & 0.731 \\
\hline & educating the effectiveness of pressurized irrigation system & 0.628 \\
\hline & educating the effectiveness of water transmission using pipes & 0.626 \\
\hline & educating the impact of improper slope of channel & 0.565 \\
\hline & educating the impact of growing season length (GSL) on water consumption & 0.519 \\
\hline & the whole role of education and promotion & 0.506 \\
\hline \multirow{3}{*}{ Economic factor } & impact of modern irrigation methods on reduction of costs & 0.675 \\
\hline & impact of modern irrigation methods on farmers' productivity & 0.599 \\
\hline & impact of farm management on water efficiency & 0.566 \\
\hline \multirow{5}{*}{ Technical factor } & conservation of modern irrigation equipment & 0.756 \\
\hline & impact of new irrigation methods on water efficiency & 0.640 \\
\hline & impact of integration on water efficiency & 0.630 \\
\hline & impact of roughness of land on water efficiency & 0.530 \\
\hline & impact of cropping pattern on water consumption & 0.513 \\
\hline \multirow{3}{*}{ Farming system factor } & role of Agricultural Water Cooperation & 0.719 \\
\hline & impact of land ownership on water consumption & 0.683 \\
\hline & distance between water resource and farm & 0.596 \\
\hline
\end{tabular}

Source: own study. 
in each factor in terms of concept, meaning and importance. Table 4 shows the fact that the experts regard institutional and legislative, educational and promotional, economic, technical and farming system factors as the most important factors affecting agricultural water management in Iran. In addition, the government's supportive policies, promoting farmers' knowledge, impact of modern irrigation methods on reduction of costs, conservation of modern irrigation equipment, and the role of agricultural water cooperation were identified as the most important components of the institutional and legislative, educational and promotional, economic, technical and farming system factors respectively.

The first component, i.e. the institutional and legislative factor was identified as the most important one affecting water management from the experts' point of view. It includes components such as role of government's supportive policies, creating the watercourse (surface water collection), imposing a ban on digging wells, optimal determination of water rate and role of performance insurance. It is worth noting that imposing a ban on digging wells and surface water collection were prioritized as among the five important components from the experts' point of view, indicating the fact that farmers expect the government to help farmers improve water consumption and also manage water consumption optimally by using supportive policies, adopting effective rules and executing them, monitoring water consumption and well digging, creating incentive water rates and localizing the performance insurance.

Consistent with the findings of the present study, HoSSEINZAD et al. [2014] showed that imposing a ban on digging wells is among the most important factors affecting water resources management in Tabriz Plains (a threefold increase in the number of illegal wells over 2004-2014 with no effective serious policy officially taken). In addition, $\mathrm{KOH}$ [2002] and GHANIAN et al. [2013] found it effective to develop a coherent legislation regarding water management in agricultural sector, which highlights the importance of institutional and legislative component.

The next important factor affecting water management from the experts' point of view is the educational-promotional one, which includes components such as promoting farmers' knowledge, educating the determination of appropriate seeding depth, educating the effectiveness of pressurized irrigation system, educating the effectiveness of water transmission using pipes, educating the impact of improper slope of channel, educating the impact of growing season length (GSL) on water consumption, and the whole role of education and promotion. This factor has been highlighted in the previous studies as well. For example, PANAHI [2012] focused on the importance and role of education and promotion on improving agricultural water management in six cities of Iran. This shows the fact that farmers need to learn the modern methods and techniques of water optimal consump- tion, determining the appropriate seeding depth, impact of growing season length on water consumption, and negative impact of improper slope of channel. They also expect officials to help them improve water consumption by holding educational-promotional courses and publishing educational and promotional magazines.

Another factor affecting agricultural water management improvement emphasized by the farmers is the economic one, which includes components such as impact of modern irrigation methods on costs reduction, impact of modern irrigation methods on farmers' productivity, and the impact of farm management on water efficiency. The farmers emphasized that insufficient personal income prevents them from implementing optimal cropping pattern proposed by officials and buying and installing modern irrigation systems which help improve water consumption. SUN et al. [2017] also showed that economic factors affect agricultural water management in northern areas of China.

From the experts' point of view, the fourth factor influencing agricultural water management is the technical one, which includes components such as conservation of modern irrigation equipment, impact of new irrigation methods on water efficiency, impact of integration on water efficiency, impact of roughness of land on water efficiency and impact of cropping pattern on water consumption. SAMIAN et al. [2015] also highlighted this factor in their studies, arguing that the optimal and correct management of water resources in Iran requires a technically transformation in agriculture otherwise the agricultural economy will be vulnerable against disasters such as drought if the current trend continues.

The final factor considered by experts is the impact of the farming system on improving agricultural water management, which includes components such as the role of agricultural water cooperation, impact of ownership of land on water consumption and the distance between water resource and farm. Improvement in farming system will undoubtedly help improve agricultural water management if an optimal use of water resources will be achieved by establishing an integrated irrigation management system. The role of Agricultural Water Cooperation as well as regulations related to ownership of lands in farming system should be strengthened. Some integrated irrigation projects are being implemented currently in Iran, such as the Irrigation Project of Abandan Sar Village in Sari on the surface of 220 ha, the Irrigation Project in Kabat Village in Sari on the surface of 80 ha and the Irrigation Project in Velame Village in Neka on the surface of 60 ha.

\section{CORRELATION BETWEEN THE FACTORS}

Table 5 summarizes the results of correlation test among the factors. The coefficients of this correlation have also been shown in this table. 
Table 5. Test of correlation between the factors $($ number $=185)$

\begin{tabular}{|c|c|c|c|c|c|c|}
\hline Factor kind & Parameter & $\begin{array}{l}\text { Institutional } \\
\text { factor }\end{array}$ & $\begin{array}{l}\text { Educational } \\
\text { factor }\end{array}$ & $\begin{array}{l}\text { Economic } \\
\text { factor }\end{array}$ & $\begin{array}{l}\text { Technical } \\
\text { factor }\end{array}$ & $\begin{array}{c}\text { Farming } \\
\text { system }\end{array}$ \\
\hline \multirow{2}{*}{$\begin{array}{l}\text { Institutional } \\
\text { and legislative }\end{array}$} & Pearson correlation coefficient & 1 & 0.427 & 0.236 & 0.504 & 0.347 \\
\hline & percentage of significance & & 0.000 & 0.000 & 0.000 & 0.000 \\
\hline \multirow{2}{*}{$\begin{array}{l}\text { Educational } \\
\text { and promotional }\end{array}$} & Pearson correlation coefficient & 0.427 & 1 & 0.404 & 0.564 & 0.495 \\
\hline & percentage of significance & 0.000 & & 0.000 & 0.000 & 0.000 \\
\hline \multirow{2}{*}{ Economic } & Pearson correlation coefficient & 0.236 & 0.404 & 1 & 0.325 & 0.418 \\
\hline & percentage of significance & 0.000 & 0.000 & & 0.000 & 0.000 \\
\hline \multirow{2}{*}{ Technical } & Pearson correlation coefficient & 0.504 & 0.564 & 0.325 & 1 & 0.549 \\
\hline & percentage of significance & 0.000 & 0.000 & 0.000 & & 0.000 \\
\hline \multirow{2}{*}{ Farming system } & Pearson correlation coefficient & 0.347 & 0.495 & 0.418 & 0.549 & 1 \\
\hline & percentage of significance & 0.000 & 0.000 & 0.000 & 0.000 & \\
\hline
\end{tabular}

Source: own study.

As the $p$-value for all of correlation tests is smaller than 0.05 , the hypothesis regarding the relationship between the factors is accepted, meaning that all of the factors are mutually associated with each other. It can also be claimed that the educational and the technical factors have the highest correlation, while the institutional-legislative and the economic factors have the lowest correlation.

\section{CONCLUSION}

The aim of this study was prioritization and analysis of the factors affecting agricultural water management from experts' point of view. At first, the importance of all factors underlying water management was evaluated based on the t-test to be significantly high. Then, the results of factor analysis identified five components, which account for over $64.29 \%$ of the total variance. These five components respectively include the institutional and legislative factor, the educational-promotional factor, the economic factor, the technical factor and the farming system factor.

Considering the results obtained from the research, we present the following suggestions to improve agricultural water management in Iran.

1. Installation of modern irrigation systems as one of the main items for license issuance of new wells.

2. Localization of irrigation equipment and devices with the aim of cost reduction in implementation of irrigation systems. All new local scientific findings should be transferred to farms to be used by farmers in order to enhance efficiency and reduce production costs.

3. Developing the watercourse in critical areas (which are threatened to soil and water salinity). Considering the fact that the water and lands in some eastern part of Iran are salty, it seems necessary to create watercourse (for surface water collection) to manage the water resources and improve the soil structure. Regarding apparent water scarcity and the low water levels, much care must be taken in issuing licenses and allocating farming programs.

4. Allocation of sufficient funds for levelling and integrating agricultural lands with the aim of reducing water consumption and increasing water efficiency.
Considering the massive investment in water management in recent decades (Alborz Dam in Amol, Golurd Dam in the East part of Iran, and Shahid Rajai dam in Sari), a unified management of water distribution on the spillway of dams will play a significant role in raising water efficiency.

5. Development of an optimal cropping pattern from flat places in central provinces up to the mountains of Alborz in the northern provinces of Iran.

\section{Acknowledgment}

Since this research has been done at Agricultural Economics Department, Islamic Azad University-Qaemshahr Branch, the authors gratefully acknowledge support from university authorities. However, this research did not receive any specific grant from funding agencies in the public, commercial, or not-for-profit sectors.

\section{REFERENCES}

Bagheri R., Hesam M., Kiani A.R., Hezarjaribi A. 2014. Emitters subsurface distribution of soil moisture the soil in different tissues. Iranian Journal of Irrigation and Drainage. No. 3(9) p. 309-407. [In Persian].

DABIRI F., Khoshnevis YAZDi S., ZANDI F. 2013. Agriculture productivity effects on the Iran economic growth. Journal of Economics and Business Research. No. 4(5) p. 17-31. [In Persian].

FORREST T.I. 2002. Principles of on-from water management [online]. Florida Cooperative Extension Services, Institute of Food and Agriculture Sciences, University of Florida. [Access 1.03.2011]. Available at: http://edis. ifas.ufl.edu/media/stats/2011Stats.xlsx

Ghanian M., Baradaran M., Alimirzaei E., Soleimani Harooni Kh., PASha S. 2013. Participatory management of agricultural water resources and its effective factors: Case study of Khozestan Province. Journal of water Research in Agriculture. No. 27(2) p. 181-190. [In Persian].

Gholami A., Habibnejad Roshan M., Shahedi K., VAFAKHAH M., SOlaymani K. 2016. Hydrological stream flow modeling in the Talar catchment (central section of the Alborz Mountains, north of Iran): Parameterization and uncertainty analysis using SWAT-CUP. Journal of Water and Land Development. No. 30 p. 57-69.

Hosseinzad J., Kazemiyeh F., Javadi A., Ghafouri H. 2014. Agricultural water management basis and mecha- 
nisms in Tabriz Plain. Water and Soil Science. No. 23(2) p. 85-98. [In Persian].

KASPERSKA-WOŁOWICZ W., ŁaBĘDZKI L. 2006. Koncepcja system monitorowania suszy na obszarach rolniczych [A concept of the system for monitoring drought in rural areas]. Woda-Środowisko-Obszary Wiejskie. T. 18. Z. 1(16) p. 161-171..

KoH M.H. 2002. Status of agricultural water in Korea: Water use and water quality. Jeonju, Korea National Institute of Agricultural Science and Technology (RDA), Korea.

Mohammadi Y., Sha'aban Alifami H., Asadi A. 2009. Farmers water management skills: Zarindasht County of Fars Province. Iranian Agricultural Extension and Education Journal. No. 5(1) p. 97-108. [In Persian].

PANAHI F. 2012. Analysis of effective factors on optimal management of water resources in Iranian agricultural sector. Agricultural Extension and Education Research. No. 5(1) p. 101-117. [In Persian].

Panahi F., MaleK-Mohammadi I., Chizari M., Samani J. 2009. The role of optimizing agricultural water resource management to livelihood poverty abolition in rural Iran. Australian Journal of Basic and Applied Sciences. No. 3(4) p. 3841-3849.

PandA R.K., BEHERA S.K., KashyaP P.S. 2004. Effective management of irrigation water for maize under stressed condition. Agricultural Water Management. No. 66(3) p. 181-203.
Pandy R.K., Maranville J.W., Admou A. 2000. Deficit irrigation and nitrogen effects on maize in a Sahelian environment. I. Grain yield and yield components. AgAgricultural Water Management. No. 46(1) p. 1-13.

SAmian M., NAderi Mahdei K., SAAdi H. Movahedi R. 2015. Identifying factors affecting optimal management of agricultural water. Journal of the Saudi Society of Agricultural Sciences. Vol. 14. Iss. 1 p. 11-18.

SHAHRESTANI H. 2014. Organizing and management of optimal water consumption in agricultural sector. Journal of Agriculture and Natural Resources Engineering System. No. 12(4) p. 37-41. [In Persian].

Shoa P., Hemmat A., Amirfattahi R., Gheysari M. 2015. Water stress monitoring in olive trees using thermal imaging. Iranian Journal of Biosystem Engineering. No. 46(4) p. 339-345. [In Persian].

Sun H., Wang S., Hao X. 2017. An improved Analytic Hierarchy Process Method for the evaluation of agricultural water management in irrigation districts of north China, Agricultural Water Management. Vol. 179 p. 324-337.

Yousefi H., Mohammadi A., MirzaAghabeik M., NOOROLLAHI Y. 2017. Virtual water evaluation for grains products in Iran. Case study: Pea and bean. Journal of Water and Land Development. No. 35 p. 275-280.

\section{Yaser FEIZABADI, Effat Masomi GORJI}

\section{Analiza efektywnych czynników w zarządzaniu wodą w rolnictwie w Iranie}

\section{STRESZCZENIE}

Celem badań była analiza czynników wpływających na gospodarkę wodną w rolnictwie w oparciu o poglądy ekspertów, z wykorzystaniem metody analizy czynnikowej. Wyniki wskazują, że zachowanie nowoczesnych urządzeń irygacyjnych, promocja wiedzy rolniczej, tworzenie cieków (gromadzenie wód powierzchniowych), wprowadzenie zakazu wiercenia nowych studni i edukacja w zakresie wydajności ciśnieniowych systemów irygacyjnych, to znane i najważniejsze czynniki wpływające na gospodarkę wodną. Ponadto, analiza czynnikowa wykazała, że pięć czynników wpływających na gospodarkę wodną w rolnictwie (systemy instytucjonalne i prawne, edukacja i promocja, system ekonomiczny i techniczny oraz gospodarka rolna) wyjaśniały 64,29\% całkowitej zmienności. W podsumowaniu sformułowano kilka sugestii co do polityki wodnej w celu usprawnienia gospodarki wodnej w rolnictwie w Iranie.

Słowa kluczowe: analiza czynnikowa, gospodarka wodna, Iran, rolnictwo 